\title{
Enhancing Safety Performance by Recognizing the Role of Perceived Management Commitment to Safety in the Jordanian Healthcare Industry: Conceptual Framework
}

\author{
Mohammad A. Al-Bsheish', Munauwar bin Mustafa², Mohd Asril Ismail³
}

\begin{abstract}
Nowadays, workplace safety is a clear concern for both individuals and organizations, particularly in developing countries such as Jordan. This is evidenced by the expanding body of safety-related literature published on this regard. This paper develops a conceptual framework of safety management based on perceived organizational support theory. The main aim of this framework is to disclose the causal links between a physiological empowerment, respect, perceived management commitment to safety and safety performance based on previous studies. Such framework could have impact on practical issues in healthcare industry, as well as enhancing the body of related literature on perceived management commitment to safety. Consequently, this framework presents a new trend concerning perceived management commitment to safety through investigating each dimension of safety climate individually.
\end{abstract}

Keywords: Healthcare industry, perceived management commitment to safety (PMCS), physiological empowerment.

Available Online: 23-01-2017

This is an open access article under Creative Commons Attribution 4.0 License, 2016.

\section{0}

\section{INTRODUCTION}

Nowadays, many organizations and countries complain of the unlimited direct and indirect outcomes of occupational accidents (Polinder et al., 2016). Despite the fact that several countries and organizations recognize the importance of refining safety level to their workers, the occupational accidents are still quite high, particularly in healthcare industry (Mccaughey et al., 2015), in the developing countries (Abozead et al., 2014; Awwad et al., 2016). For instance, American Nurses Association (ANA) reported that $40 \%$ of nurses complained of nonfatal injuries (Nixon et al., 2015). Moreover, $75 \%$ of nurses were exposed to Needle Stick Injuries (NSIs) in Jordan, whereas $47 \%$ of them were not reported as having

\footnotetext{
${ }^{1}$ School of Business Management, Universiti Utara Malaysia, Malaysia. E-mail: gandour1984@yahoo.com

${ }^{2}$ School of Business Management, Universiti Utara Malaysia, Malaysia. E-mail: munawar@uum.edu.my

3 School of Technology Management linguistics, Universiti Utara Malaysia, Malaysia. E-mail: azril@uum.edu.my
} 
incidence (Abozead et al., 2014). However, several previous studies showed that improving safety performance is significant to reduce occupational accidents and maintain workplace safety (Siu et al., 2004; Zohar, 2000, Liu et al., 2015). Hence, many scholars investigated the safety performance indicators (Jiang et al ., 2010; Khdair et al., 2011; Nahrgang et al., 2007; Neal et al., 2000). They found that the best indicator of safety performance is safety climate (Nahrgang et al., 2007; Swedler et al., 2015). In this regard, safety climate is supposed to be a subset of organization climate (Coyle et al., 1995; Huang et al., 2006; Neal et al., 2000; Zohar, 1980). Safety climate is defined by Zohar (1980) as a summary of molar perceptions that employees share about their work environment. Likewise, Neal and Griffin (2002) described the employees' perceptions of safety policies, procedures, and practices in the workplace as safety climate. However, debates of the nature of safety climate is still being, for example, Ghahramani and Khalkhali (2015) supported that specific safety climate dimensions and scales are still needed in each work field. On the other hand, Zohar (2014) argued that emerging extra safety climate scales could affect negatively on safety climate research progress.

Most previous studies considered safety climate as a multidimensional construct (Bosak et al., 2013; Guo et al., 2016; Huang et al., 2006; Vinodkumar \& Bhasi, 2009; Zohar, 1980), though they disagreed in relation to the required dimensions (Coyle et al., 1995; Zohar, 2014, 2008). Hence, perceived management commitment to safety (PMCS) represents the strongest dimension that configures safety climate among employees rather than other safety climate dimensions (Konjin et al., 2015; Christian et al., 2009; Nielsen et al., 2008). Additionally, it is the strongest predictor of safety performance among different industries (Liu et al., 2015; Guo et al., 2016). Nevertheless, there are few studies that focused on studying PMCS independently to assure workplace safety. Consequently, this paper proposes a framework based on this perception to achieve workplace safety in the Jordanian healthcare industry. Furthermore, there are limited studies conducted to explore the antecedents of PMCS. This could be explained by focusing on safety climate as a whole and neglect searching the antecedent of each dimension of them.

\subsection{UNDERPINNING THEORY}

This study employs the organizational support theory (OST) as being supportive to conceptual framework. Primarily, OST was presented by Eisenberger et al. (1986). This theory maintained and established the employers and their employees' mutual relationship through the social exchange perspective. OST is a contemporary meaning for social exchange theory. In this sense, employees who perceive the organizational support to their well-being and general welfare will be more likely to perceive the organization care to their safety as well. Eisenberger et al. (1986) also suggested that employees' perception about the organization's care for their well-being will be positively related to achieve desirable work-related outcomes (Liu et al., 2015; Zohar, 1980). Previous studies used safety as a crucial element to employees' well-being. Moreover, increasing the perceived organizational supports will inspire the employees to work firmer and exhibit attitudes that are compatible with the organizations' goals and objectives (Eisenberger et al., 2001). This conceptual paper proposed that perceived psychological empowerment, respect, and PMCS could improve safety performance in the Jordanians healthcare industry. This, in turn, motivates employees to reciprocate these actions by increasing compliance to safety rules, willingness to participate in safety programs and cooperation with co-workers regarding safety issues. However, employee's perception of management commitment to safety is related to perceived organizational support and managers-subordinators social exchange relationship in safety literature (Michael et al., 2005). Safety literature also inspected the perceived organizational support with safety-related behaviors and accidents (Hofmann \& Morgeson, 1999). Theory of perceived organizational support (POS) was applied in several previous studies (Hofmann \& Morgeson, 1999; Mearns \& Reader, 2008). Based on the above, this framework utilizes POS theory as underpinning theory.

\subsection{SAFETY PERFORMANCE}

Usually, safety performance concept focuses on maintaining safe workplace through different interventions (Burke et al., 2002). These interventions that attain safety performance are mainly safety behaviors (Neal et al., 2000). Sequentially, safety behavior is represented at least by two dimensions 
(Andriessen, 1978; Neal \& Griffin, 2006; Neal et al., 2000; Vinodkumar \& Bhasi 2010). Accordingly, safety performance is represented by the safety related behaviors (safety compliance and safety participation). Furthermore, Siu et al. (2003) concentrate on accidents and occupational injuries and considered the safety performance as the ability to minimize the quantity of accidents and occupational injuries in the work sites. Some researchers also pointed out that safety performance is the possibility of work places accidents that may lead to serious injuries or even deaths (Huang et al., 2006).

As acknowledged previously, safety performance could be labeled as individual metrics or organizational metrics (Christian et al., 2009). Recognizing the employees' behavior regarding safety in the workplaces is a vigorous practical matter in occupational safety (Beus et al., 2016)

Accordingly, Neal and Griffin (1997) generated a model to interpret safety performance by accepting the safety compliance and safety participation as safety performance components. In this sense, the safety compliance means "adhering to safety procedures and carrying out work in a safe manner", while the safety participation refers to "the behaviors that may not directly contribute to workplace safety, but they do help to develop an environment that supports safety" (Neal et al., 2000). Additionally, Neal et al. (2000) and Vinodkumar and Bhasi (2010) described the safety performance as safety compliance and safety participation based on the general job performance theory which has been developed by Motowidlo and Van Scotter (1994) who considered the contextual performance and task performance to be comparable to safety participation and safety compliance respectively (Motowidlo and Van Scotter, 1994).

In the last decade, research efforts were devoted to investigate the predictors of safety performance. For instance, Gershon et al. (2000); Zohar (1980); Mohamed (2002); Swedler et al. (2015) found the safety climate predictor; Neal et al. (2000); Vinodkumar and Bhasi (2010); Christian et al. (2009) recognized the predictors of safety motivation and safety knowledge; Kapp (2012) and Mullen et al. (2011) concluded the safety leadership predictor; Sampson et al. (2014) found the predictor of occupational safety stressors; Lee and Dalal (2016) recognized the personality trait predictor; Li et al. (2013) and Turner et al. (2012) revealed the predictors of job demands and job resources.

In fact, safety performance level is still under expectation, particularly in the developing countries such as Jordan (Abozead et al., 2014; Hassan et al., 2008). Hence, safety performance requires accessing other predictors in order to achieve workplace safety. Accordingly, this paper proposes a conceptual framework for enhancing safety performance by inspecting the antecedents of PMCS, which is considered as the strongest predictor of safety performance.

\subsection{PERCEIVED MANAGEMENT COMMITMENT TO SAFETY (PMCS)}

Since the creation of safety climate concept by Zohar in 1980, PMCS has become an essential dimension of this construct. PMCS could be regarded as the best management requirement in safety related issues in the workplaces (Zohar, 1980). PMCS is described as "the extent to which management is perceived to place a high priority on safety, communicate, and act on safety issues effectively" (Neal \& Griffin, 2004). In fact, PMCS has been debated primarily as being one of the necessary factors for the success of safety programs (Cohen, 1977), as well as being associated with low accidents quantity in industrial plants (Smith et al., 1987). Zohar (1980) found that PMCS was a significant dimension to influence safety performance among manufacturing samples. Abudayyeh et al. (2006) indicated that PMCS is an efficient technique to reduce costs related to accidents outcomes. Furthermore, Yule et al. (2007) indicated that risk-taking behaviors is affected by PMCS as well.

In this respect, numerous studies revealed the significant role of PMCS comparing to other safety climate dimensions. Nielsen et al. (2008) also argued that PMCS is an essential dimension of safety climate. Likewise, Konjin et al. (2015) found that PMCS and employees' involvement are the main safety climate dimensions. While Zohar (2014) opined that PMCS is a core meaning of safety climate (Zohar, 2008). Nevertheless, most studies still utilized the safety climate as a multidimensional construct. 
Additionally, it could be contested that the achievement of other safety climate dimensions, such as safety training, is partially dependent on the degree of PMCS (Huang et al., 2006). Moreover, the stream body of safety climate literature confirmed empirically the role of PMCS to influence safety performance behaviors. In detail, Mohamed's (2002) findings reported that PMCS has the strongest influence safety behavior $(t=3.95, p<0.001)$. Vinodkumar and Bhasi $(2010)$ also revealed the direct paths between perceived management commitment and safety compliance behavior $(\beta=0.169, p<0.01)$. Likewise, Liu et al. (2015) indicated that PMCS was the most proximal antecedent of safety compliance behavior ( $\beta=$ $0.169, p<0.001)$. Christian et al. (2009) reported that PMCS influences the safety behavior positively. In addition, the findings of McGonagle et al. (2016) exhibited that PMCS has a positive relationship with safety performance behaviors $(p<.001)$. While Subramaniam et al. $(2016)$ showed that PMCS was the most significant predictor of safety participation behaviors $(\beta=0.473, p<0.01)$. Zohar (2014) also proposed that safety outcomes depend on employees' perception of honest management commitment to safety. Similarly, Hofmann et al. (1995) supported that employees should perceive safety concerns in management words and deeds. These findings indicate the important role of PMCS in achieving safety performance which motivates the scholars to search extensively the factors that strengthen the perception positively in the workplaces.

\subsection{PSYCHOLOGICAL EMPOWERMENT}

Employees' empowerment has been presented to advance human resources in workplaces (Zare et al., 2015). The concept of empowerment includes employees being offered a great level of flexibility and participation of decisions making process (Greasley et al., 2005). The previous studies classified empowerment into two types: psychological and structural (Cicolini et al., 2014). Psychological empowerment represents the employees' perception regarding empowerment (Thomas \& Velthouse, 1990). Therefore, it is a multidimensional construct formed by employees' cognitive understanding of work setting (Conger and Kanungo 1988). Spreitzer (1995) stated that psychological empowerment has four related dimensions (meaning, competence, self-determination, impact). This conceptualization has been approved by many scholars, such as Indradevi (2012) and Malik et al. (2013).

Accordingly, employees' empowerment has become important, especially in the workplaces that contain professionalized staff such as healthcare organizations (Irvine et al., 1999). Healthcare providers, such as physicians and nurses, have typically enthused to conduct their work in a self-directed manner. However, dealing with varied cases of patients in a complex environment requires additional efforts contrasting working in other industries (Irvine et al., 1999). Hence, empowerment could be necessary among healthcare providers (Irvine et al., 1999). In spite of the importance of psychological empowerment to improve work outcomes (Ghani et al., 2009; Khany \& Tazik, 2016; Saif \& Saleh, 2013), few studies have investigated physiological empowerment with safety outcomes (Tong et al., 2015).

However, prior studies examined the impact of psychological empowerment empirically on many job outcomes. For instance, Ghani et al. (2009) indicated that psychological empowerment explained $11 \%$ of the innovative variances in the Malaysian context. Likewise, psychological empowerment has a positive significant relationship with innovative behavior among Dutch registered nurses (Knol \& Van Linge, 2009).

Additionally, psychological empowerment affects job satisfaction (Khany \& Tazik, 2016; Saif \& Saleh, 2013), job performance (Indradevi, 2012), nursing practices environment (Wang \& Liu, 2013), process engagement (Zhang \& Bartol, 2010), quality of patient care (Bonias et al., 2010), workers' commitment (Malik et al., 2013), and perceived management commitment to quality (Howard \& Foster, 1999). However, previous studies confirmed that there is a relation between quality and safety as work-related outcomes (Wanberg et al., 2013).

Overall, there is an evident link between psychological empowerment and work outcomes such as innovative behaviors, job performance, satisfaction, and quality care. However, existing literature does not pay attention to examining the role of psychological empowerment on PMCS as well as safety 
performance. Thus, the current paper contributes to the existing safety literature by adding a new antecedent, namely psychological empowerment, to PMCS and safety performance.

\subsection{RESPECT EMPLOYEES}

Respect is a complicated concept; a developed understanding of respect could improve the workers' ability to give respect and receive it, as well as coping with the matter when not receiving respect (DeLellis, 2000). Faulkner and Laschinger (2008) defined respect as a positive action resulted from employees' perception, usually known as an ethical virtue. Hence, respect and dignity could share the same meaning in sociology (Faulkner \& Laschinger, 2008). Respect denotes the recognition that an individual is a full human being (Sennett, 2003). It is notable that respecting employees through achieving their requests within workplace undertakings is central to attain "quality of work life" (Howard \& Foster, 1999). Commonly, respect refers to anything improves the employees' self-esteem and gives them a feeling of appreciation and recognition which, in turn, enhances their work outcomes (Kusluvan et al., 2010).

Respect issue is critical and important in the healthcare context. Previous studies have examined respect issue among nurses. For example, Laschinger (2004) indicated that the absence of respect is a major factor influencing the quality of nurses' work life because nurses appreciate respect value more than monetary incentives. Additionally, National Advisory Council on Aging 2003-2004 reported that disrespecting nurses is the major cause of low-quality care of patients, poor performance, and personal stress (Boyle \& Kochinda, 2004).

El-Said (2014) revealed the significant relationship between respect and morale. Ulrich et al. (2005) stated that respect has four elements: attention, deference, valuing, and appropriate conduct. McGuire et al. (2003) revealed that nurse's satisfaction is predicted by the level of respect they receive from their managers and co-workers. Walker (2014) indicated that management practices represent a source of respect among employees, as well as affecting the employees' behaviors. Burchell and Robin (2011) argued that respect is a fundamental value inside the organization and obtaining the respect employees' environment is critical to achieving a "great workplace". The lack of respect affects employees' intention to leave (Augsberger et al., 2012). Howard and Foster (1999) indicated the positive relationship between respect feeling and perceived management commitment to quality $(\beta=.38, p<.0001)$.

Overall, the relationship between respect employees and work outcomes like innovative behaviors, job performance, satisfaction, and quality care were recognized in the aforementioned literature. However, few studies investigated the impact of respect on safety performance among nurses. Thus, the current paper contributes to the existing safety literature by adding a new antecedent, namely respect employees, to PMCS and safety performance.

\subsection{CONCEPTUAL FRAMEWORK}

This conceptual framework supposed that psychological empowerment and respect influence the PMCS and safety performance. Based on the strong relationship between PMCS and safety performance found in previous studies, the mediation role of PMCS is expected among psychological empowerment, respect and safety performance. Thus, it is acknowledged that this conceptual framework of safety performance plays a significant role in identifying the antecedents of PMCS to assist healthcare industry to improve safety performance which, in turn, maintains the workplace safety.

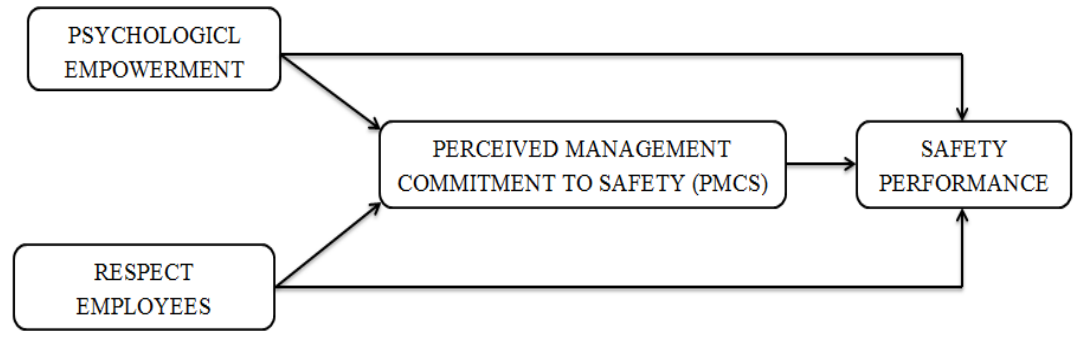

Figure 1: Conceptual framework 


\subsection{CONCLUSION AND RECOMMENDATION}

This conceptual paper discusses the safety performance framework for healthcare industry by presenting the antecedents of PMCS and safety performance. Previous safety performance studies recognized the safety climate importance in order to change safety performance behaviors, particularly PMCS, with a limited focus on preceding part of this relationship (antecedents of safety climate dimensions). This conceptual paper employed the perceived organizational support theory to support this framework. This study contributed to the existing literature by theoretically demonstrating that PMCS is the most important variable of safety climate dimensions. Moreover, it inspected the PMCS antecedents including psychological empowerment and respect employees. The current study revealed the possible role of PMCS as a mediator between these antecedents. However, this study recommends investigating more antecedents of PMCS in order to enhance the safety performance.

\section{REFERENCES}

Abozead, S. E., Abuhasheesh, M., Nawafleh, H., Kawafha, M. M., \& Al-tarawneh, O. (2014). Knowledge and practices of Jordanian nurses on needlestick injuries : An evaluative study. Infectious Diseases in Clinical Practice, 23(1), 1-5.

Abudayyeh, O., Fredericks, T. K., Butt, S. E., \& Shaar, A. (2006). An investigation of management's commitment to construction safety. International Journal of Project Management, 24(2), 167-174. http://doi.org/10.1016/j.ijproman.2005.07.005

Andriessen, J. H. T. H. (1978). Safe behaviour and safety motivation. Journal of Occupational Accidents, 1(4), 363-376. http://doi.org/10.1016/0376-6349(78)90006-8

Augsberger, A., Schudrich, W., McGowan, B. G., \& Auerbach, C. (2012). Respect in the workplace: A mixed methods study of retention and turnover in the voluntary child welfare sector. Children and Youth Services Review, 34(7), 1222-1229. http://doi.org/10.1016/j.childyouth.2012.02.0

Awwad, R., El Souki, O., \& Jabbour, M. (2016). Construction safety practices and challenges in a Middle Eastern developing country. Safety Science, 83, 1-11. http://doi.org/10.1016/j.ssci.2015.10.0

Beus, J. M., McCord, M. A., \& Zohar, D. (2016). Workplace safety: A review and research synthesis. Organizational Psychology Review, 1-30. http://doi.org/10.1177/2041386615626243

Bonias, D., Bartram, T., Leggat, S. G., \& Stanton, P. (2010). Does psychological empowerment mediate the relationship between high performance work systems and patient care quality in hospitals? Asia Pacific Journal of Human Resources, 48(3), 319-337. http://doi.org/10.1177/1038411110381667

Bosak, J., Coetsee, W. J., \& Cullinane, S. J. (2013). Safety climate dimensions as predictors for risk behavior. Accident Analysis and Prevention, 55, 256-264. http://doi.org/10.1016/j.aap.2013.02.022

Boyle, D. K., \& Kochinda, C. (2004). Enhancing collaborative communication of nurse and physician leadership in two intensive care units. J Nurs Adm, 34(2), 60-70. http://doi.org/10.1097/00005110200402000-00003

Burchell, M., \& Robin, J. (2011). The great workplace: How to build it, how to keep it, and why it matters. John Wiley \& Sons.

Burke, M. J., Sarpy, S. A., Tesluk, P. E., \& Smith-Crown, K. (2002). General safety performance: A test of a grounded theoretical model. Personnel Psychology, 55(2), 429-457. http://doi.org/10.1111/j.17446570.2002.tbo0116.x

Christian, M. S., Bradley, J. C., Wallace, J. C., \& Burke, M. J. (2009). Workplace safety: A meta-analysis of the roles of person and situation factors. Journal of Applied Psychology, 94(5), 1103-1127. http://doi.org/10.1037/a0016172

Cicolini, G., Comparcini, D., \& Simonetti, V. (2014). Workplace empowerment and nurses ' job satisfaction : A systematic literature review. Journal of Nursing Management, 22(7), 855-871. http://doi.org/10.1111/jonm.12028

Cohen, A. (1977). Factors in successful occupational safety programs. Journal of Safety Research, 9(4), 168-178. http://doi.org/10.1016/j.jsr.2013.07.04

Conger, J. A., \& Kanungo, R. N. (1988). The empowerment process: Integrating theory and practice. 
Academy of Management Review, 13(3), 471-482. http://doi.org/10.5465/AMR.1988.4306983

Coyle, I. R., Sleeman, S. D., \& Adams, N. (1995). Safety climate. Journal of Safety Research. http://doi.org/10.1016/0022-4375(95)00020-Q

DeLellis, A. J. (2000). Clarifying the concept of respect: Implications for leadership. Journal of Leadership Studies, 7(2), 35-49.

Eisenberger, R., Armeli, S., Rexwinkel, B., Lynch, P. D., \& Rhoades, L. (2001). Reciprocation of perceived organizational support. The Journal of Applied Psychology, 86(1), 42-51. http://doi.org/10.1037//00219010.86.1.42

Eisenberger, R., Huntington, R., Hutchison, S., \& Sowa, D. (1986). Perceived organizational support. Journal of Applied Psychology. http://doi.org/10.1037/0021-9010.75.1.51

El-Said, O. A. (2014). Impacts of respect, support, and teamwork on hotel employees' morale in Egypt. Anatolia: An International Journal of Tourism and Hospitality Research, 25(2), 211-227. http://doi.org/10.1080/13032917.2013.856330

Faulkner, J., \& Laschinger, H. (2008). The effects of structural and psychological empowerment on perceived respect in acute care nurses. Journal of Nursing Management, 16(2), 214-221. http://doi.org/10.1111/j.1365-2834.2007.00781.x

Gershon, R. R., Karkashian, C. D., Grosch, J. W., Murphy, L. R., Escamilla-Cejudo, A., Flanagan, P. A., ... Martin, L. (2000). Hospital safety climate and its relationship with safe work practices and workplace exposure incidents. American Journal of Infection Control, 28(3), 211-21. http://doi.org/10.1067/mic.2000.105288

Ghahramani, A., \& Khalkhali, H. R. (2015). Development and validation of a safety climate scale for manufacturing industry. Safety and Health at Work, 6(2), 97-103. http://doi.org/10.1016/j.shaw.2015.01.003

Ghani, N. A. A., Hussin, T. A. B. S. R., \& Jusoff, K. (2009). The impact of psychological empowerment on lecturers' innovative behaviour in Malaysian private higher education institutions. Canadian Social Science, 5(4), 54-63.

Greasley, K., Bryman, A., Dainty, A., Price, A., Soetanto, R., \& King, N. (2005). Employee perceptions of empowerment, 27(4), 354-368. Retrieved from http://dx.doi.org/10.1108/01425450510605697

Guo, B. H. W., Yiu, T. W., \& González, V. A. (2016). Predicting safety behavior in the construction industry: Development and test of an integrative model. Safety Science, 84, 1-11. http://doi.org/10.1016/j.ssci.2015.11.020

Hassan, Z. M., Wahsheh, M. A., Shishani, K. R., \& Pryor, E. R. (2008). Hepatitis needs assessment among Jordanian healthcare workers. International Nursing Review, 55(2), 142-147. http://doi.org/10.1111/j.1466-7657.2007.00583.x

Hofmann, D. A., \& Morgeson, F. P. (1999). Safety-related behavior as a social exchange: The role of perceived organizational support and leader-member exchange. Journal of Applied Psychology, 84(2), 286-296. http://doi.org/10.1037/0021-9010.84.2.286

Hofmann, D. A., Jacobs, R., \& Landy, F. (1995). High reliability process industries: Individual, micro, and macro organizational influences on safety performance. Journal of Safety Research, 26(3), 131-149. http://doi.org/10.1016/0022-4375(95)00011-E

Howard, L. W., \& Foster, S. T. (1999). The influence of human resource practices on empowerment and employee perceptions of management commitment to quality. Journal of Quality Management, 4(I), $5-22$.

Huang, Y.-H., Smith, G. S., Ho, M., \& Chen, P. Y. (2006). The relationship between safety climate and injury rates across industries: The need to adjust for injury hazards. Accident Analysis and Prevention, 38(3), 556-562. http://doi.org/10.1016/j.aap.2005.11.013

Indradevi, R. (2012). The impact of psychological empowerment on job performance and job satisfaction in Indian software companies. International Journal of Multidisciplinary Management Studies, 2(4), 36-48.

Irvine, D., Leatt, P., Evans, M. G., \& Baker, R. G. (1999). Measurement of staff empowerment within health service organizations. Journal of Nursing Measurement, 7(1), 79-95.

Jiang, L., Yu, G., Li, Y., \& Li, F. (2010). Perceived colleagues' safety knowledge/behavior and safety performance: Safety climate as a moderator in a multilevel study. Accident Analysis and Prevention, 42(5), 1468-1476. http://doi.org/10.1016/j.aap.2009.08.017 
Kapp, E. A. (2012). The influence of supervisor leadership practices and perceived group safety climate on employee safety performance. Safety Science, 50(4), 1119-1124. http://doi.org/10.1016/j.ssci.2011.11.011

Khany, R., \& Tazik, K. (2016). On the relationship between psychological empowerment, trust, and Iranian EFL teachers job satisfaction: The case of secondary school teachers. Journal of Career Assessment, 24(1), 112-129. http://doi.org/10.1177/1069072714565362

Khdair, W. A., Shamsudin, F. M., \& Subramanim, C. (2011). Improving safety performance by understanding relationship between management practices and leadership behavior in the oil and gas industry in Iraq: A Proposed Model. Health, 22, 23.

Knol, J., \& Van Linge, R. (2009). Innovative behaviour: The effect of structural and psychological empowerment on nurses. Journal of Advanced Nursing, 65(2), 359-370. http://doi.org/10.1111/j.13652648.2008.04876.x

Konjin, Z. N., Shokoohi, Y., Zarei, F., \& Rahimzadeh, M. (2015). Dimensions of safety climate among Iranian nurses. Int J Occup Environ Med, 6, 223-231. Retrieved from www.theijoem.com

Kusluvan, S., Kusluvan, Z., Ilhan, I., \& Buyruk, L. (2010). The human dimension: A review of human resources management issues in the tourism and hospitality industry. Cornell Hospitality Quarterly, 51(2), 171-214. http://doi.org/10.1177/1938965510362871

Laschinger, H., Finegan, J., Shamian, J., \& Wilk, P. (2004). A longitudinal analysis of the impact of workplace empowerment on work satisfaction. Journal of Organizational Behavior, 25, 527-545. http://doi.org/10.5465/APBPP.2002.7516663

Lee, S., \& Dalal, R. S. (2016). Climate as situational strength: Safety climate strength as a cross-level moderator of the relationship between conscientiousness and safety behaviour. European Journal of Work and Organizational Psychology, 25(1), 120-132. http://doi.org/10.1080/1359432X.2014.987231

Li, F., Jiang, L., Yao, X., \& Li, Y. (2013). Job demands, job resources and safety outcomes: The roles of emotional exhaustion and safety compliance. Accident Analysis and Prevention, 51, 243-251. http://doi.org/10.1016/j.aap.2012.11.029

Liu, X., Huang, G., Huang, H., Wang, S., Xiao, Y., \& Chen, W. (2015). Safety climate, safety behavior, and worker injuries in the Chinese manufacturing industry. Safety Science, 78, 173-178. http://doi.org/10.1016/j.ssci.2015.04.023

Malik, F., Chugtai, S., Iqbal, Z., \& Ramzan, M. (2013). Does psychological empowerment bring about employee commitment? evidence from telecommunication sector of Pakistan. Journal of Business Studies Quarterly, 5(1), 14-21.

Mccaughey, D., Turner, N., Kim, J., Dellifraine, J., \& Mcghan, G. E. (2015). Examining workplace hazard perceptions \& employee outcomes in the long-term care industry. Safety Science, 78, 190-197. http://doi.org/10.1016/j.ssci.2015.04.013

McGonagle, A. K., Childress, N. M., Walsh, B. M., \& Bauerle, T. J. (2016). Can civility norms boost positive effects of management commitment to safety? The Journal of Psychology, 150(5), 591-605. http://doi.org/10.1080/00223980.2016.1143798

McGuire, M., Houser, J., Jarrar, T., Moy, W., \& Wall, M. (2003). Retention: It's all about respect. The Health Care Manager, 22(1), 38-44. http://doi.org/10.1097/00126450-200301000-00007

Mearns, K. J., \& Reader, T. (2008). Organizational support and safety outcomes: An un-investigated relationship? Safety Science, 46(3), 388-397. http://doi.org/10.1016/j.ssci.2007.05.002

Michael, J. H., Evans, D. D., Jansen, K. J., \& Haight, J. M. (2005). Management commitment to safety as organizational support: Relationships with non-safety outcomes in wood manufacturing employees. Journal of Safety Research, 36(2), 171-179. http://doi.org/10.1016/j.jsr.2005.03.002

Mohamed, S. (2002). Safety climate in construction site environments. Journal of Construction Engineering and Management, 128(5), 375-384. http://doi.org/10.1061/(ASCE)07339364(2002)128:5(375)

Motowidlo, S. J., \& Van Scotter, J. R. (1994). Evidence that task performance should be distinguished from contextual performance. Journal of Applied Psychology, 79(4), 475-480. http://doi.org/10.1037/0021-9010.79.4.475

Mullen, J. E., Kelloway, E. K., \& Teed, M. (2011). Inconsistent style of leadership as a predictor of safety behaviour. Work \& Stress, 25(1), 41-54. http://doi.org/10.1080/02678373.2011.569200

Nahrgang, Jennifer D, F. P. M., \& Hofmann, D. A. (2007). Predicting safety performance: A meta-analysis 
of safety and organizational constructs. In 22nd Annual Conference of the Society for Industrial and Organizational Psychology, New York, NY (pp. 1-21). http://doi.org/10.1017/CBO9781107415324.004

Neal, A. \& Griffin, M.A. April, 1997, 'Linking theories of work performance and safety climate', paper presented at the 12th Annual conference of the Society for Industrial Psychology, St. Louis, Missouri.

Neal, A., \& Griffin, M. A. (2004). Safety climate and safety at work. In In M. R. Frone \&J. Barling (Eds.), The psychology of workplace safety (pp. 15-34). Washington, DC: American Psychological Association.

Neal, A., \& Griffin, M. A. (2006). A study of the lagged relationships among safety climate, safety motivation, safety behavior, and accidents at the individual and group levels. Journal of Applied Psychology, 91(4), 946-953. http://doi.org/10.1037/0021-9010.91.4.946

Neal, A., M.A.Griffin, \& P.M.Hart. (2000). The impact of organizational climate on safety climate and individual behavior. Safety Science, 34(1-3), 99-109. http://doi.org/10.1016/S0925-7535(00)00008-4

Nielsen, K. J., Rasmussen, K., Glasscock, D., \& Spangenberg, S. (2008). Changes in safety climate and accidents at two identical manufacturing plants. Safety Science, 46(3), 440-449. http://doi.org/10.1016/j.ssci.2007.05.00

Nixon, A. E., Lanz, J. J., Manapragada, A., Bruk-Lee, V., Schantz, A., \& Rodriguez, J. F. (2015). Nurse safety: How is safety climate related to affect and attitude? An International Journal of Work, Health \& Organisations, 29(4), 401-419. http://doi.org/10.1080/02678373.2015.1076536

Polinder, S., Haagsma, J., Panneman, M., Scholten, A., Brugmans, M., \& Beeck, E. Van. (2016). The economic burden of injury: Health care and productivity costs of injuries in the Netherlands. Accident Analysis and Prevention, 93, 92-100. http://doi.org/10.1016/j.aap.2016.04.003

Saif, N. I., \& Saleh, A. S. (2013). Psychological empowerment and job satisfaction in Jordanian hospitals. International Journal of Humanities and Social Science, 3(16), 250-257.

Sampson, J. M., DeArmond, S., \& Chen, P. Y. (2014). Role of safety stressors and social support on safety performance. Safety Science, 64, 137-145. http://doi.org/10.1016/j.ssci.2013.11.025

Sennett, R. (2003), Respect - the formation of character in a world of inequality, Penguin Books, London. Siu, O. L., Phillips, D. R., \& Leung, T. W. (2003). Age differences in safety attitudes and safety performance in Hong Kong construction workers. Journal of Safety Research, 34(2), 199-205. http://doi.org/10.1016/S0022-4375(02)00072-5

Siu, O. L., Phillips, D. R., \& Leung, T. W. (2004). Safety climate and safety performance among construction workers in Hong Kong: The role of psychological strains as mediators. Accident Analysis and Prevention, 36, 359-366. http://doi.org/10.1016/S0001-4575(03)00016-2

Smith, M., Cohen, H., Cohen, A. and Cleveland, R. (1987). Characteristics of successful safety programs. Journal of Safety Research, 10(1), 5-15.

Spreitzer, G. (1995). Psychological empowerment in the workplace: Dimensions, measurement, and validation. Academy of Management Journal, 38(5), 1442-1465. http://doi.org/10.1177/1534484312461635

Subramaniam, C., Subramaniam, C., Mohd. Shamsudin, F., Mohd. Shamsudin, F., Mohd Zin, M. L., Mohd Zin, M. L., ... \& Hassan, Z. (2016). Safety management practices and safety compliance in small medium enterprises: Mediating role of safety participation. Asia-Pacific Journal of Business Administration, 8(3). http://doi.org/http://dx.doi.org/10.1108/APJBA-02-2016-0029

Swedler, D. I., Verma, S. K., Huang, Y. H., Lombardi, D. A., Chang, W. R., Brennan, M., \& Courtney, T. K. (2015). A structural equation modelling approach examining the pathways between safety climate, behaviour performance and workplace slipping. Occupational and Environmental Medicine, 1-6. http://doi.org/10.1136/oemed-2014-102496

Thomas, K. W., \& Velthouse, B. A. (1990). Cognitive elements of empowerment: An "interpretive" model of intrinsic taks motivation. The Academy of Management Review, 15(4), 666-681. http://doi.org/10.5465/AMR.1990.4310926

Tong, D. Y. K., Rasiah, D., Tong, X. F., \& Lai, K. P. (2015). Leadership empowerment behaviour on safety officer and safety teamwork in manufacturing industry. Safety Science, 72, 190-198. http://doi.org/10.1016/j.ssci.2014.09.009

Turner, N., Stride, C. B., Carter, A. J., McCaughey, D., \& Carroll, A. E. (2012). Job Demands-ControlSupport model and employee safety performance. Accident Analysis \& Prevention, 45, 811-817. http://doi.org/10.1016/j.aap.2011.07.005

Ulrich, B. T., Buerhaus, P. I., Donelan, K., Norman, L., \& Dittus, R. (2005). How RNs view the work 
environment : Result of a national survey of registered nurses. The Journal of Nursing Administration, 35(5), 389-396.

Vinodkumar, M. N., \& Bhasi, M. (2009). Safety climate factors and its relationship with accidents and personal attributes in the chemical industry. Safety Science, 47(5), 659-667. http://doi.org/10.1016/j.ssci.2008.09.004

Vinodkumar, M. N., \& Bhasi, M. (2010). Safety management practices and safety behaviour: Assessing the mediating role of safety knowledge and motivation. Accident Analysis \& Prevention, 42(6), 20822093.

Walker, A. N. (2014). The Examination of Organizational Respect in Relation to Organizational Culture.

Wanberg, J., Harper, C., Hallowell, M. R., \& Rajendran, S. (2013). Relationship between construction safety and quality performance. Journal of Construction Engineering and Management, 139(10).

Wang, S., \& Liu, Y. (2013). Impact of professional nursing practice environment and psychological empowerment on nurses' work engagement: Test of structural equation modelling. Journal of Nursing Management, 23(3), 287-296. http://doi.org/10.1111/jonm.12124

Yule, S., Flin, R., \& Murdy, A. (2007). The role of management and safety climate in preventing risk-taking at work. International Journal of Risk Assessment and Management, 7(2), 137-150. http://doi.org/10.1504/IJRAM.2007.011727

Zare, M., Zarmehr, F., \& Ashrafi-Rizi, H. (2015). Relationship between psychological empowerment and productivity of medical librarians. Acta Informatica Medica, 23(3), 142-146. http://doi.org/10.5455/aim.2015.23.142-146

Zhang, X., \& Bartol, K. M. (2010). Linking empowering leadership and employee creativity: the influence of psychological empowerment, intrinsic motivation, and creative process management. Academy of Management Journal, 53(1), 107-128.

Zohar, D. (1980). Safety climate in industrial organizations: Theoretical and applied implications. The Journal of Applied Psychology, 65(1), 96-102.

Zohar, D. (2000). A group-level model of safety climate: Testing the effect of group climate on microaccidents in manufacturing jobs. The Journal of Applied Psychology, 85(4), 587-596.

Zohar, D. (2008). Safety climate and beyond: A multi-level multi-climate framework. Safety Science, 46(3), 376-387. http://doi.org/10.1016/j.ssci.2007.03.006

Zohar, D. (2014). Safety climate: Conceptualization, measurement, and improvement. In The Oxford handbook of organizational climate and culture (pp. 317-334). 